\title{
Isolation of Mercury-binding Peptides in Vegetative Parts of Chromolaena odorata
}

Malona P. Velasco-Alinsuga,b,*, Gilda C. Rivero ${ }^{\mathrm{a}, \mathrm{c}}$, and

Titos Anacleto O. Quibuyen ${ }^{\mathrm{d}}$

a Institute of Biology, College of Science, University of the Philippines, Diliman 1101,

Quezon City, Philippines

b Biology Department, College of Science, University of the Philippines, Governor Pack Rd., Baguio City 2600, Philippines. Fax: (6374) 444-3128. E-mail: malonski@yahoo.com

c Office of the Vice Chancellor for Research \& Development, University of the Philippines, Diliman 101, Quezon City, Philippines

d Institute of Chemistry, College of Science, University of the Philippines, Diliman 1101, Quezon City, Philippines

* Author for correspondence and reprint requests

Z. Naturforsch. 60c, 252-259 (2005)

Mercury-binding peptides from roots, stems, and leaves of Hg-treated Chromolaena odorata plants were isolated and partially characterized using RP-HPLC and ESI-MS. Upon exposure of $C$. odorata plants to high concentrations of 1.0 and $2.0 \mu \mathrm{M} \mathrm{Hg}\left(\mathrm{NO}_{3}\right)_{2}$ treatments from $0-28$ days, they accumulated as much as $125 \mathrm{mg} / \mathrm{g}$ (dry wt) $\mathrm{Hg}$ in the roots, $15.280 \mathrm{mg} /$ $\mathrm{g}$ (dry wt) $\mathrm{Hg}$ in the stems, and $0.800 \mathrm{mg} / \mathrm{g}$ (dry wt) $\mathrm{Hg}$ in the leaves indicating that $C$. odorata has a high potential as a phytoremediation agent of inorganic mercury. The plant's ability to accumulate and sequester $\mathrm{Hg}$ ions was primarily attributed to the production of $\mathrm{Hg}$ binding peptides, which were initially detected through the use of Ellman's reagent. Isolation techniques using RP-HPLC equipped with a C18 column manifested a single prominent peak consistently appearing at a retention time of $2.6-2.8 \mathrm{~min}$ in all the plant samples treated with different $\mathrm{Hg}$ concentrations at varying lengths of exposure. Further characterization of this prominent peak using electrospray ionization mass spectrometry revealed the presence of a peptide containing several cysteine residues with the highest peak concentration recorded at $91 \mathrm{mV}$ and $89 \mathrm{mV}$ in roots and stems of plants treated with $2.0 \mu \mathrm{M} \mathrm{Hg}\left(\mathrm{NO}_{3}\right)_{2}$ for $4 \mathrm{wk}(P<$ $0.05)$ and $85 \mathrm{mV}$ in leaves treated with $1.0 \mu \mathrm{M} \mathrm{Hg}\left(\mathrm{NO}_{3}\right)_{2}$ for 1 wk.

Key words: Chromolaena odorata, Phytoremediation, Phytochelatin

\section{Introduction}

In a $\mathrm{Hg}$-contaminated mine tailings dumpsite in Itogon, Benguet, Philippines, the noxious weed Chromolaena odorata (L.f.) R. M. King et H. Robinson was surveyed to be one of the most dominant in the area accumulating highly toxic levels of $\mathrm{Hg}$ concentrations. The high tolerance of $C$. odorata plants to phytotoxic concentrations of $\mathrm{Hg}$ can be attributed to the presence of $\mathrm{Hg}$-binding peptides which function to scavenge intracellular $\mathrm{Hg}$ ions translocated by the plant into its system away from its essential metabolic activities. However, the chelation of the $\mathrm{Hg}$ ion by a ligand may come in the form of organic acids, amino acids, or Cys-containing peptides (Briat and Lebrun, 1999).

Metal induced, sulfhydryl-rich peptides known as phytochelatins (PCs) have been described as effective chelators and detoxifiers of heavy metal ions. Several types of phytochelatins which are produced by varying types of plants with different heavy metal $(\mathrm{Cd}, \mathrm{Pb}, \mathrm{Cu})$ treatments have been successfully isolated and sequenced. The differences are primarily due to variants of GSH, the precursor of phytochelatins, with different C-terminal residues found in some plants. The most prevalent phytochelatins synthesized from GSH in most plants have a glycine C-terminus $(\gamma$-GluCys) $n$-Gly ( $n=2$ to 11) (Grill et al., 1987; Hayashi and Mutoh, 1994; Mehra, 1998; Ohtake et al., 1990; Zenk, 1996). In other plants, however, no glycine C-terminus was found producing repeating sequences of ( $\gamma$-Glu-Cys)n (Grill et al., 1986). Plants synthesizing homoglutathione in place of GSH produce phytochelatins with Ala at its C-terminus ( $\gamma$-Glu-Cys) $n$-Ala (Grill et al., 1987). Moreover, four sets of phytochelatin peptides have recently been discovered; all are homologous to GSH but with different $\mathrm{C}$-terminal residues. One contains $\beta$-alanine instead of glycine thus named homophy- 
tochelatin (h-PC) with the following sequence: $(\gamma$ Glu-Cys) $n$ - $\beta$-Ala ( $n=2$ to 7 ) (Grill et al., 1987). These are prevalent in order Fabales, family Phaseoleae (Zenk, 1996). However, plants in the Poaceae family contain hydroxymethyl-GSH synthesizing hydroxymethyl-PCs with the following sequence: ( $\gamma$-Glu-Cys) $n$-Ser (Klaphek et al., 1994). Another set of peptides, $(\gamma$-Glu-Cys $) n$-Glu, is also induced by Cd in maize (Meuwly et al., 1995). And more recently, roots of Cd-treated horseradishes were detected to have ( $\gamma$-Glu-Cys) $n$-Gln using electrospray ionization mass spectroscopy (Kubota et al., 2000).

Unfortunately, no plant has yet been identified to naturally hyperaccumulate mercury (Henry, 2000; Raskin and Ensley, 2000). Only transgenic plants such as Arabidopsis thaliana, Liriodendron tulipifera, and Nicotiana tabacum which were inserted with bacterial mer A and mer B genes to convert $\mathrm{Hg}^{2+}$ to $\mathrm{Hg}^{0}$ and methyl mercury to $\mathrm{Hg}^{2+}$ were developed to provide potential phytoremediation steps in alleviating $\mathrm{Hg}$-polluted areas (Bizily et al., 1997; Rugh et al., 1996, 1998).

Moreover, studies involved in extracting and isolating phytochelatins induced by $\mathrm{Hg}$ treatments in higher plants have not been well elucidated. In a study conducted by Satoh et al. (1999), high levels of nonproteinaceous thiol-containing compounds were exhibited by a unicellular green algae, Tetraselmis tetrethele (Prasinophyceae), upon mercury and cadmium exposure. However, no phytochelatins have been detected. Further identification of these thiol-containing compounds using HPLC reveals the presence of glutathione and a tripeptide, Arg-Arg-Glu, which appears to bind and scavenge $\mathrm{Hg}$ and $\mathrm{Cd}$ ions. In higher plants, further isolation and characterization of $\mathrm{Hg}$-binding peptides remain to be explored. Thus, it was the objective of this study to isolate, identify, and partially characterize the $\mathrm{Hg}$-binding peptides involved in $C$. odorata.

\section{Materials and Methods}

\section{Plant material and $\mathrm{Hg}$ treatment}

Cuttings of Chromolaena odorata plants measuring $10-12 \mathrm{~cm}$ in height were surface sterilized for $5 \mathrm{~s}$ using hydrogen peroxide, then washed with sterilized water three times. Plants were grown in 10 -l basins $(12 \times 6 \times 4)$ filled with $1 / 2$ strength Hoagland's solution with $0.01 \%$ indole acetic acid (IAA) to induce root formation. After $2 \mathrm{wk}$ of ac- climatization and root formation, these seedlings were subjected to $\mathrm{Hg}$ treatments with modified $1 / 2$ Hoagland's solution. Inorganic mercury in the form of $\mathrm{Hg}\left(\mathrm{NO}_{3}\right)_{2}$ (Merck Brand, 99.9\%$100.5 \%$ ) was used to prepare 2 concentrations, i.e., 1.0 and $2.0 \mu \mathrm{M} \mathrm{Hg}\left(\mathrm{NO}_{3}\right)_{2}$, which were added to the nutrient solution. $30 \mathrm{ml}$ of deionized water were added everyday to maintain solution volume. $\mathrm{Nu}$ trient solution was maintained at $\mathrm{pH}$ 6.5. Harvests were done after 1 wk every wk for 4 consecutive wks.

\section{Determination of total $\mathrm{Hg}$ content}

Total $\mathrm{Hg}$ content was determined using CV-AAS (thermo Jarrel Ash Atomic Absorption Spectro Video 11e) as subscribed from the methods of Kloke (1981). Harvested plant samples were initially sprayed with $0.1 \mathrm{~m}$ EDTA at the roots. Plants were then separated into roots, stems, and leaves, air-dried for $24 \mathrm{~h}$, digested overnight in conc. $\mathrm{HNO}_{3}$, then submitted to the Institute of Chemistry for CV-AAS analyses.

Harvested plants from each $\mathrm{Hg}$ concentration were segregated into roots, stems, and leaves. $2-\mathrm{cm}$ samples from each of the plant parts were specifically cut from the following: (1) root tip, $0.5 \mathrm{~cm}$ from tip; (2) stem, $1 \mathrm{~cm}$ above base of stem cutting; (3) petiole of leaf at the $2^{\text {nd }}$ node from stem base; and (4) base of leaf from the $2^{\text {nd }}$ node. These were preserved in FAA then subjected to microtechnique using saffranin red and fast green as stains.

\section{Extraction, fractionation, and isolation of Hg-binding biomolecules}

Extraction methods used to isolate the $\mathrm{Hg}$-binding peptides were adopted from Grill et al. (1986) and Keltjens and van Beusichem (1998) with some modifications. $1 \mathrm{~g}$ of the plant material was washed with deionized water, freeze-dried with liquid nitrogen, and homogenized for $5 \mathrm{~min}$ in $10 \mathrm{ml}$ of $\mathrm{N}_{2}$-saturated extraction solution $(5 \% \mathrm{w} / \mathrm{v}$ sulfosalicylic acid added to $6.3 \mathrm{~nm}$ diethylenetriaminepentaacetic acid) using a mortar and pestle. The homogenate was centrifuged for $45 \mathrm{~min}$ at 3,000 rpm at $4{ }^{\circ} \mathrm{C}$. The supernatant was subjected immediately to gel filtration using Sephadex G-50 (1.5 × $92 \mathrm{~cm}$ ), equilibrated with $0.05 \mathrm{~m}$ sodium phosphate buffer ( $\mathrm{pH}$ 7.6). The plant extract was eluted at a flow rate of $30 \mathrm{ml} / \mathrm{h}$ and each of the fifteen 10 $\mathrm{ml}$ fractions collected was spectrophotometrically 
monitored for SH-containing compounds. A $200-\mu \mathrm{l}$ aliquot from each of the 15 fractions was mixed with $1 \mathrm{ml}$ of $0.2 \mathrm{M}$ Tris- $\mathrm{HCl}(\mathrm{pH} 8.2)$ and $0.15 \mathrm{ml}$ of $10 \mathrm{~mm} \quad 5^{\prime}, 5^{\prime}$-dithiobis-nitrobenzoic acid (DTNB) were added. These were incubated in ice for $20 \mathrm{~min}$ then spectrophotometrically read at $412 \mathrm{~nm}$. Peak fractions detected to contain 0.200 $\mathrm{OD}$ and higher amounts of SH-containing compounds were pooled and lyophilized prior to RPHPLC analysis.

Isolation of $\mathrm{Hg}$-binding peptides was subscribed from the methods of Grill et al. (1987) with some modifications from Bruns et al. (1999), Kubota et al. (1995), and Vogeli-Lange and Wagner (1990). Approx. $0.1 \mathrm{mg}$ of the precipitates pooled from the lyophilized fractions was dissolved in $0.5 \mathrm{ml}$ of $20 \%$ acetonitrile in $0.1 \%$ TFA. $25 \mu \mathrm{l}$ of the sample was injected into a C18 analytical column (Inertsil ODS-80A, $4.6 \mathrm{~mm}$ i.d. $\times 250 \mathrm{~mm}$ ) using reverse phase high performance liquid chromatography (Shimadzu LC-10AD) for optimization and detection purposes. The gradient conditions were controlled by a system controller (Shimadzu SCL$10 \mathrm{~A})$ with $20 \%$ acetonitrile in $0.1 \%(\mathrm{v} / \mathrm{v})$ TFA as solvent with a flow rate of $1 \mathrm{ml} / \mathrm{min}$. Detection was set at $214 \mathrm{~nm}$. Prominent peaks were collected separately and lyophilized for further analyses.

\section{Partial characterization of the Hg-binding peptides}

Partial characterization of the Hg-binding peptides was subscribed from the methods of $\mathrm{Ku}$ bota et al. (2000) with some modifications. Lyophilized samples isolated as prominent peaks from RP-HPLC were dissolved in pure methanol (Merck, HPLC grade) and subsequently introduced into an electrospray ionization mass spectrometer (Thermo Quest LCQ) by infusion. In addition, approx. $0.1 \mathrm{~g}$ of the lyophilized peak sample was digested with conc. $\mathrm{HNO}_{3}$ and subjected to CV-AAS analyses to confirm if these peaks isolated from RP-HPLC were bound to mercury.

\section{Results and Discussion}

Total Hg content

Chromolaena odorata plants generally exhibited high $\mathrm{Hg}$ uptake in the different $\mathrm{Hg}$ treatments at varying lengths of exposure $(P<0.001)$. Among the three vegetative organs, the roots accumulated the highest levels of $\mathrm{Hg}$ compared to stems and leaves $(P<0.001)$. Total $\mathrm{Hg}$ levels were measured per dry wt of samples. As presented in Fig. 1A, the roots of $C$. odorata plants contained the highest amounts of total $\mathrm{Hg}$ accumulating as much as $125 \mathrm{mg} / \mathrm{g} \mathrm{Hg}$ after $4 \mathrm{wk}$ of $2.0 \mu \mathrm{M} \mathrm{Hg}\left(\mathrm{NO}_{3}\right)_{2}$ treatment $(P<0.05)$ compared to the stems (Fig. 1B) which localized $15 \mathrm{mg} / \mathrm{g} \mathrm{Hg}$ after 4 wk of $2.0 \mu \mathrm{M}$ $\mathrm{Hg}\left(\mathrm{NO}_{3}\right)_{2} \quad(P<0.05)$ and finally, the leaves (Fig. 1C) translocated as much as $880 \mu \mathrm{g} / \mathrm{g} \mathrm{Hg}$ (dry wt) after $3 \mathrm{wk}$ of $2.0 \mu \mathrm{M} \mathrm{Hg}\left(\mathrm{NO}_{3}\right)_{2}(P<0.05)$.

Mercury treatments of 1.0 and $2.0 \mu \mathrm{M} \mathrm{Hg}\left(\mathrm{NO}_{3}\right)_{2}$ after 1 to 4 wk induced highly significant levels of $\mathrm{Hg}$ in the roots $(P<0.001)$. At $1.0 \mu \mathrm{M} \mathrm{Hg}\left(\mathrm{NO}_{3}\right)_{2}$ concentration, the roots accumulated $3,000 \mu \mathrm{g} / \mathrm{g}$ $\mathrm{Hg}$ after $1 \mathrm{wk}$ of $\mathrm{Hg}$ exposure $(P<0.05)$ which radically increased to $16,500 \mu \mathrm{g} / \mathrm{g} \mathrm{Hg}$ after $2 \mathrm{wk}$ of the same treatment $(P<0.05)$. However, after 3 wk of treatment, $\mathrm{Hg}$ levels dramatically decreased to $4,200 \mu \mathrm{g} / \mathrm{g}(P<0.05)$. Although at $4 \mathrm{wk}$ of $\mathrm{Hg}$ exposure, $\mathrm{Hg}$ levels drastically escalated to $42,700 \mu \mathrm{g} / \mathrm{g} \mathrm{Hg}(P<0.05)$ with the plant showing no signs of stress morphologically. Similarly, at $2.0 \mu \mathrm{M} \mathrm{Hg}\left(\mathrm{NO}_{3}\right)_{2}$ treatment, the roots translocated higher amounts of intracellular $\mathrm{Hg}$ contents of $14,800 \mu \mathrm{g} / \mathrm{g} \mathrm{Hg}$ after $1 \mathrm{wk}(P<0.05)$ but $\mathrm{Hg}$ levels significantly dropped to $3,800 \mu \mathrm{g} / \mathrm{g} \mathrm{Hg}$ after $2 \mathrm{wk}$ of the same treatment $(P<0.05)$. However, the mercury contents gradually increased after $3 \mathrm{wk}$ of $2.0 \mu \mathrm{M} \mathrm{Hg}\left(\mathrm{NO}_{3}\right)_{2}$ treatment to $4,200 \mu \mathrm{g} / \mathrm{g} \mathrm{Hg}(P<$ $0.05)$ then peaked to $125,600 \mu \mathrm{g} / \mathrm{g} \mathrm{Hg}$ after $4 \mathrm{wk}$ of the same $\mathrm{Hg}$ treatment $(P<0.05)$.

The stems similarly accumulated significant amounts of $\mathrm{Hg}$ after 4 wk of $1.0(P<0.001)$ and $2.0 \mu \mathrm{M} \mathrm{Hg}\left(\mathrm{NO}_{3}\right)_{2}$ treatment $(P<0.001)$ as exhibited in Fig. 1B. At $1.0 \mu \mathrm{M} \mathrm{Hg}\left(\mathrm{NO}_{3}\right)_{2}$ treatment, $800 \mu \mathrm{g} / \mathrm{g} \mathrm{Hg}$ were localized in the stem after $1 \mathrm{wk}$ $(P<0.05)$ which increased to $1,000 \mu \mathrm{g} / \mathrm{g} \mathrm{Hg}$ after 2 wk $(P<0.05)$. Amounts of $\mathrm{Hg}$ further escalated to $1,200 \mu \mathrm{g} / \mathrm{g}(P<0.05)$ and doubled to $2,400 \mu \mathrm{g} / \mathrm{g}$ after 4 wk of $\mathrm{Hg}$ treatment in the stem $(P<0.05)$. Moreover, C. odorata plants treated with $2.0 \mu \mathrm{M}$ $\mathrm{Hg}\left(\mathrm{NO}_{3}\right)_{2}$ concentrated relatively significant amounts of $\mathrm{Hg}$ in the stem $(P<0.001)$. An estimated $120 \mu \mathrm{g} / \mathrm{g} \mathrm{Hg}$ were localized in the stem after $1 \mathrm{wk}$ of $2.0 \mu \mathrm{M} \mathrm{Hg}\left(\mathrm{NO}_{3}\right)_{2}$. This increased to $2,100 \mu \mathrm{g} / \mathrm{g} \mathrm{Hg}$ after $2 \mathrm{wk}(P<0.05)$ but declined rapidly to $860 \mu \mathrm{g} / \mathrm{g} \mathrm{Hg}$ after $3 \mathrm{wk}(P<0.05)$. However, total $\mathrm{Hg}$ content was recorded to be at its highest $(15,300 \mu \mathrm{g} / \mathrm{g})(P<0.05)$ in the stems after $4 \mathrm{wk}$ of $2.0 \mu \mathrm{M} \mathrm{Hg}\left(\mathrm{NO}_{3}\right)_{2}$ treatment.

In addition, as manifested in Fig. $1 \mathrm{C}$, the different $\mathrm{Hg}$ treatments at varying lengths of exposure generally did not cause any significant in- 
A

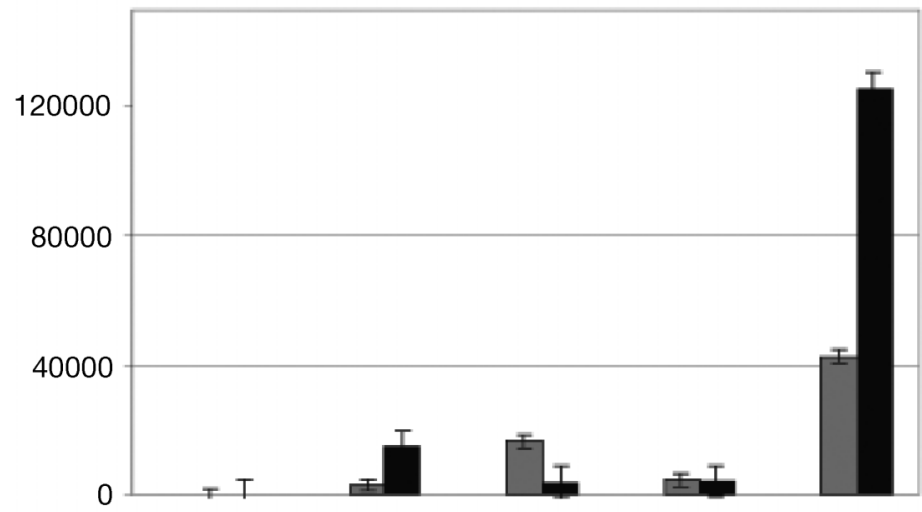

$\mathrm{B}$

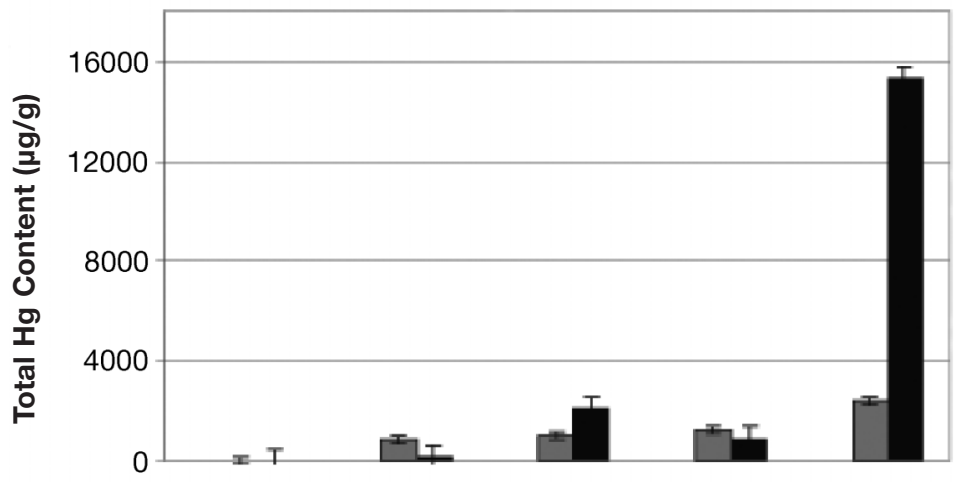

C

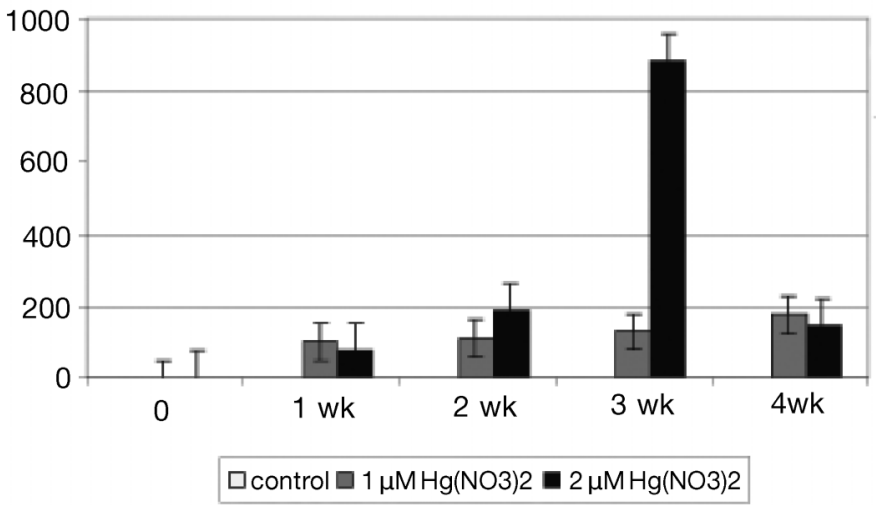

Fig. 1. Total $\mathrm{Hg}$ content in (A) roots, (B) stems, and (C) leaves of Chromolaena odorata after $\mathrm{Hg}$ treatments. Values are means with standard error $(n=3)$. creases in the total $\mathrm{Hg}$ content in the leaves $(P=$ $0.986)$ except after 3 wk of $2.0 \mu \mathrm{M} \mathrm{Hg}\left(\mathrm{NO}_{3}\right)_{2}$ treatment wherein there was a significant increase of $880 \mu \mathrm{g} / \mathrm{g} \mathrm{Hg}(P<0.05)$.

\section{Tissue localization of $\mathrm{Hg}$}

Cross-sections of roots, stems, and leaves of $\mathrm{Hg}$ treated plants generally exhibited an aggregation of dark, granular deposits that were totally absent in untreated plants. These dark clusters appeared to increase in size with higher $\mathrm{Hg}$ treatments and longer exposure periods to the treatments. In roots (Fig. 2A) of plants treated with $1 \mu \mathrm{M} \mathrm{Hg}\left(\mathrm{NO}_{3}\right)_{2}$ after 1 and $2 \mathrm{wk}$, black granular aggregations were found at the root epidermal layers as well as cortical tissues. However, after 2 to $4 \mathrm{wk}$ of $1.0 \mu \mathrm{M}$ $\mathrm{Hg}\left(\mathrm{NO}_{3}\right)_{2}$ and 1 to 4 wk of $2.0 \mu \mathrm{M} \mathrm{Hg}\left(\mathrm{NO}_{3}\right)_{2}$ treat- 


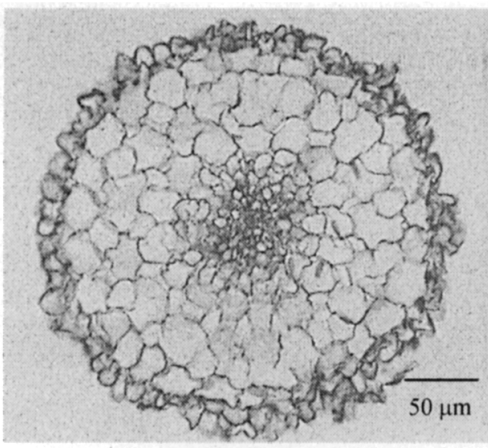

A1

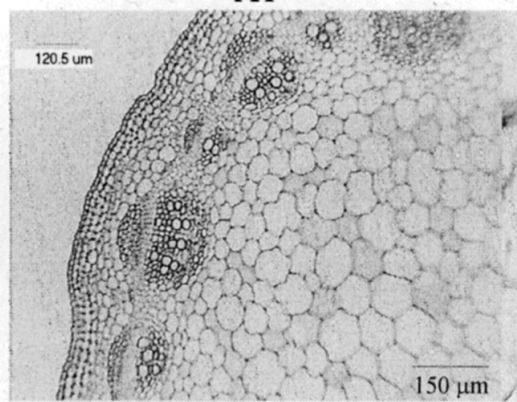

B1

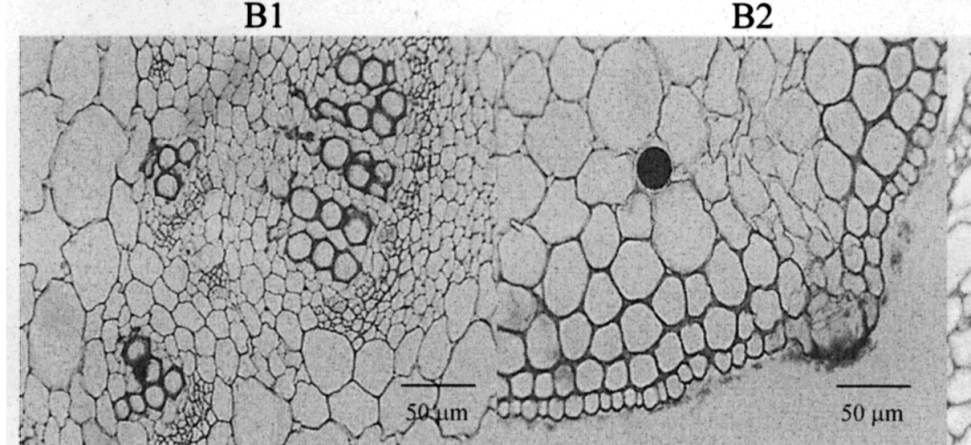

C1

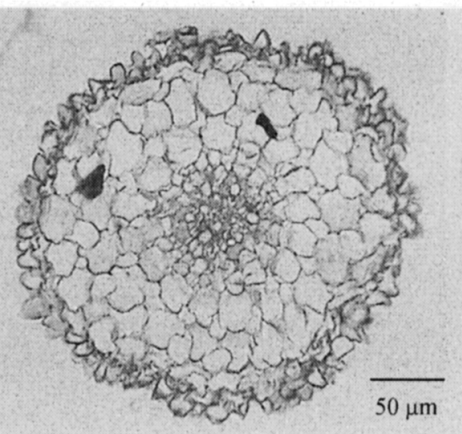

A2
C2

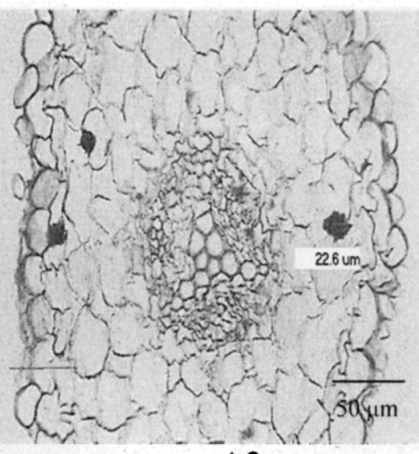

A3

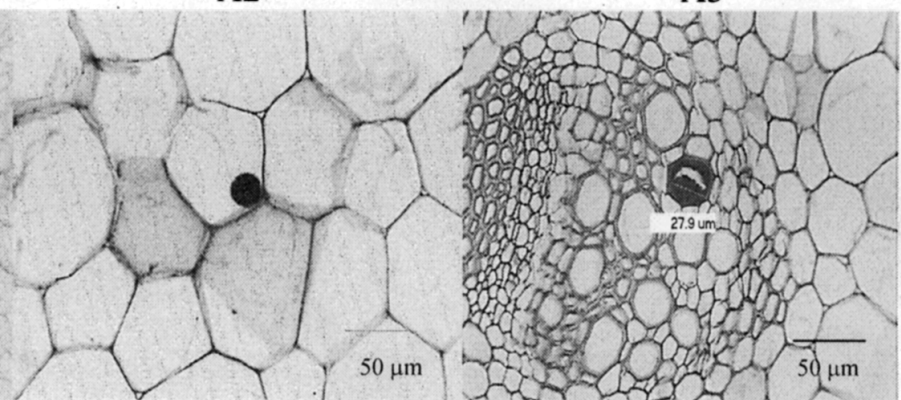

B3

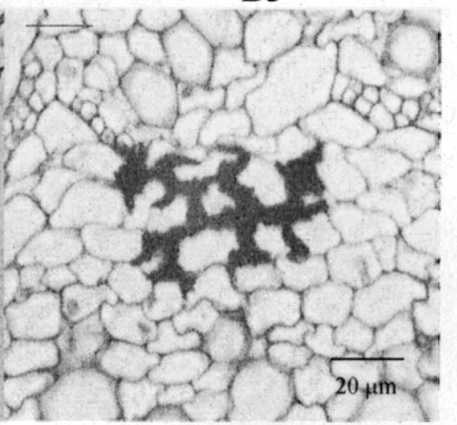

C3

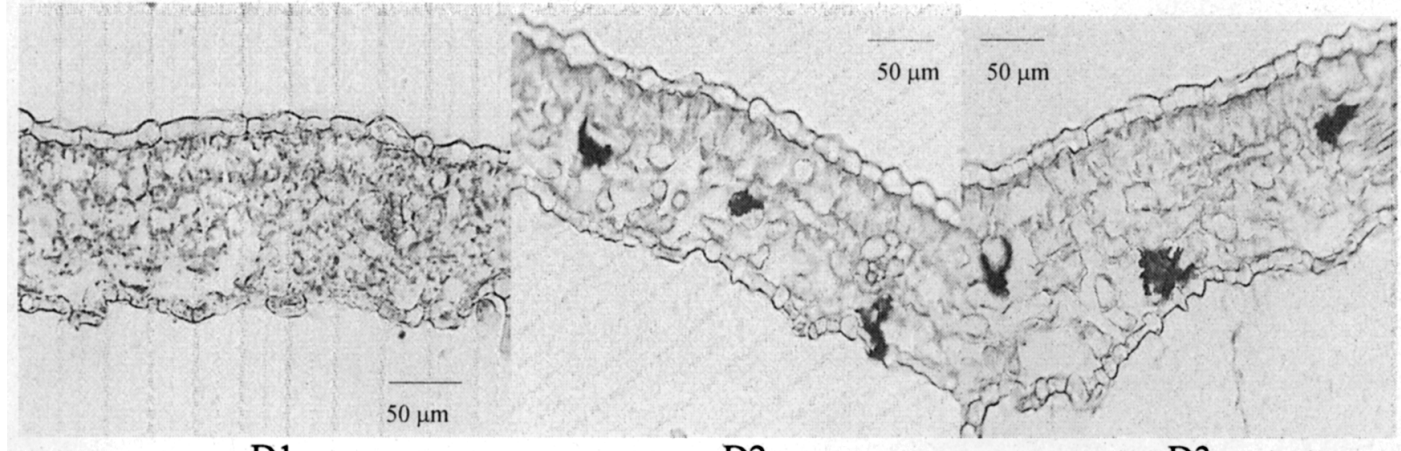

D1

D2

D3

Fig. 2. Cross sections of roots at (A1) control (400x), (A2) $1.0 \mu \mathrm{M} \mathrm{Hg}\left(\mathrm{NO}_{3}\right)_{2}$ for 2 wk (400x), (A3) $2.0 \mu \mathrm{M} \mathrm{Hg}\left(\mathrm{NO}_{3}\right)_{2}$ for $4 \mathrm{wk}(400 \mathrm{x})$; stems at (B1) control (100x), (B2) $1.0 \mu \mathrm{M} \mathrm{Hg}\left(\mathrm{NO}_{3}\right)_{2}$ for 2 wk (400x), (B3) $2.0 \mu \mathrm{M} \mathrm{Hg}\left(\mathrm{NO}_{3}\right)_{2}$ for 4 wk (400x); petiole with (C1) $1.0 \mu \mathrm{M} \mathrm{Hg}\left(\mathrm{NO}_{3}\right)_{2}$ for 2 wk (400x), (C2) $1.0 \mu \mathrm{m} \mathrm{Hg}\left(\mathrm{NO}_{3}\right)_{2}$ for 3 wk (400x), (C3) $2.0 \mu \mathrm{M}$ $\mathrm{Hg}\left(\mathrm{NO}_{3}\right)_{2}$ for $4 \mathrm{wk}(1,000 \mathrm{x})$; and leaves at (D1) control (400x), (D2) $1.0 \mu \mathrm{M} \mathrm{Hg}\left(\mathrm{NO}_{3}\right)_{2}$ for $2 \mathrm{wk}(400 \mathrm{x})$, (D3) $2.0 \mu \mathrm{M}$ $\mathrm{Hg}\left(\mathrm{NO}_{3}\right)_{2}$ for $2 \mathrm{wk}(400 \mathrm{x})$. Diameters $(\mu \mathrm{m})$ of granular deposits were measured in A3 and B3. 
ment, these dark aggregations were found to penetrate through the endodermis moving further into the xylem vessels while some were still confined at the epidermal and cortical tissues. In stems, as exhibited in Fig. 2B, these black granular deposits were localized in the stem cortical parenchyma cells after $1 \mathrm{wk}$ then at the xylem and pith after $2-4$ wk of $1.0 \mu \mathrm{M} \mathrm{Hg}\left(\mathrm{NO}_{3}\right)_{2}$ treatment. At $2.0 \mu \mathrm{M}$ $\mathrm{Hg}\left(\mathrm{NO}_{3}\right)_{2}$ treatment, these deposits were more pronounced in the xylem vessels after 1 wk exposure, then became visible at the stem pith parenchyma cells after 2 to $4 \mathrm{wk}$ exposure. Figs. $2 \mathrm{C}$ and $2 \mathrm{D}$, on the other hand, present cross-sections of petiole and leaves of treated and untreated plants. Cross-sections of petiole and leaves of control were totally devoid of dark aggregates; however, these black aggregates were detected at epidermal outgrowths such as trichomes and epidermal layer of petioles from all the treated plants. Moreover, leaf cross-sections of $\mathrm{Hg}$-treated plants from 1 to 4 wk treatments similarly exhibited dark granular deposits in both the spongy and mesophyll layer and xylem vessels.

However, deposits of electron dense dark, granular spots, which we believe are the accumulated $\mathrm{Hg}$ because of its absence in all the control plants, appeared to be small in the root epidermal layer. These black granules clustered into bigger aggregates and localized in the parenchyma cells of the cortex. However, the biggest dark granular spots were found in the dead cells of the xylem illustrating further that the accumulated $\mathrm{Hg}$ was translocated upstream. The roots contained the highest $\mathrm{Hg}$ levels simply because they have a greater surface area to absorb and localize $\mathrm{Hg}$ into their epidermis, cortex, and xylem. These are then loaded in the xylem sap and translocated to the aerial parts of the plants through transpirational stream and stomatal conductance. Thus, high levels of $\mathrm{Hg}$ content were similarly found in stems and leaves. Dark aggregations of granular spots were confined in parenchymatous cells of the cortex and pith, which renders the $\mathrm{Hg}$ ions less toxic and away from the plant's basic metabolic activities. Moreover, since there were no electron dense, dark granular deposits found in the phloem, there was only an upward transport of mercury and no redistribution from leaves to roots. Thus, the leaves may have served as a waste depot of mercury particularly in the trichomes and mesophyll layer of the leaves in both the spongy and palisade cells.

\section{Hg-binding peptides}

Detection and isolation techniques conducted using RP-HPLC revealed only one prominent peak, which appeared at 2.6-2.8 $\mathrm{min}$ in all the $\mathrm{Hg}$ treated plant samples corresponding to the elution time of cysteine. This was similarly one of the findings of Kubota et al. (1995) wherein cysteine, GSH, and phytochelatins were identified as the $\mathrm{SH}$ containing compounds involved in Cd detoxification in normal root cultures of Rubia tinctorum. Cysteine particularly eluted at a retention time of $2.8 \mathrm{~min}$. However, the relative concentration of this peak varied significantly which increased at higher $\mathrm{Hg}$ treatments $(P<0.001)$ and at longer $\mathrm{Hg}$ exposures $(P<0.001)$. All the control samples from the vegetative parts generally did not exhibit any peak at $214 \mathrm{~nm}$. Mercury-treated roots, stems, and leaves were observed to contain relatively high amounts of this single prominent peak. Moreover, root concentrations of this peak appeared to increase at longer $\mathrm{Hg}$ treatment indicating that prolonged $\mathrm{Hg}$ exposure induces the synthesis of cysteine to deal with the increased $\mathrm{Hg}$ uptake of the plant. The highest peak concentration was recorded at $91 \mathrm{mV}$ in roots and $89 \mathrm{mV}$ in stems of plants treated with $2.0 \mu \mathrm{M} \mathrm{Hg}\left(\mathrm{NO}_{3}\right)_{2}$ for $4 \mathrm{wk}(P<$ $0.05)$. However, in leaves, the highest peak concentration was exhibited by $1.0 \mu \mathrm{M} \mathrm{Hg}\left(\mathrm{NO}_{3}\right)_{2}$ treated plants for $1 \mathrm{wk}$ at $85 \mathrm{mV}$. Moreover, after 2 wk of varying $\mathrm{Hg}$ treatments, lyophilized samples from leaf extracts started to exhibit 2 prominent peaks. The first peak eluted at an earlier retention time of $1.663 \mathrm{~min}$ and the second peak at $2.796 \mathrm{~min}$. It was also observed that treatments with higher $\mathrm{Hg}$ concentrations and longer $\mathrm{Hg}$ exposures for two to four wk induced the synthesis of one to two more prominent peaks.

Based on the ESI-MS chromatogram of the isolated peak samples, the similarity between the peaks isolated from the roots, stems, and leaves in the first five ion peaks $(\mathrm{m} / \mathrm{z}, 142.5,183,262,381$, and 403) indicates that the $\mathrm{Hg}$-binding peptides found in all the vegetative parts of the $\mathrm{Hg}$-treated plant may have the same basic component or parent material. The repeating sequences of $\mathrm{m} / z, 119$ observed in all the samples corresponds to the exact mass of cysteine. However, the amino acid cysteine was not detected in mass spectrometry because the molecular weight of cysteine is below limitation for detection assuming that there are individual amino acids of cysteine. It appears, however, that a series of five to nine cysteine residues 
are repetitively attached to this long chain of $\mathrm{Hg}$ binding peptide. Based on their respective mass spectra, the $\mathrm{Hg}$-binding peptide isolated from the roots exhibits five cysteine residues while those isolated from the stems and leaves contain as much as nine cysteine residues which may affect their binding capacities with $\mathrm{Hg}$. Moreover, the molecular ion peaks exhibited by the stem and leaf isolates were highly similar differing only in terms of the relative abundance of the individual monomers. In addition, the molecular ion base peak in the stems and leaves were relatively similar (i.e., $\mathrm{m} / \mathrm{z}, 619.9$ and 620.1, respectively) indicating further that the $\mathrm{Hg}$-binding peptides isolated from these vegetative parts may be one and the same and functionally localized in the shoots to translocate $\mathrm{Hg}$ ions upstream. Although the molecular ion base peak exhibited by the roots was relatively lighter $(\mathrm{m} / \mathrm{z} 522.5)$, this ion peak was also found in high quantities in both stem and leaf isolates.

In addition, some of the ion peaks corresponding with ( $\gamma$-Glu-Cys)2 (desGly-PC2) at $m / z$. 500.6 and ( $\gamma$-Glu-Cys) 3 -Gly at $m / z$. 804.9 were also detected. Moreover, an ion peak at $\mathrm{m} / z 946.1$ also appeared in all the samples analyzed which corresponds to an ion peak of ( $\gamma$-Glu-Cys)4 (desGlyPC4) found in the roots of Rubia tinctorum L. by Kubota et al. (2000). However, an ion peak, which corresponded with the exact mass of $\gamma$-Glu-CysGly, commonly known as glutathione, was particularly found only in the root isolates.
CV-AAS analyses of peaks isolated from the roots contained a total $\mathrm{Hg}$ content of 1.26$2.23 \mu \mathrm{g} / \mathrm{g}$. However, purified stem and leaf samples contained significantly $(P<0.05)$ higher $\mathrm{Hg}$ levels of $21-23 \mu \mathrm{g} / \mathrm{g}$ and $30 \mu \mathrm{g} / \mathrm{g}$, respectively. It is likely that the $\mathrm{Hg}$ ion forms a double bond with the sulfur of cysteine producing cinnabar, which is quite stable in the environment. This implies a promising phytoremediation agent for $\mathrm{Hg}$ which is costeffective and low maintenance performing both phytoextraction and phytostabilization. Chromolaena odorata is a perennial plant that persists all throughout the year and tolerates a variety of harsh conditions without the application of fertilizers. Although it is known as a noxious weed, its efficacy and potential to alleviate Hg-contaminated areas would far outweigh its disadvantages. Thus, even when the plant sheds off its leaves, dies and decomposes in the natural environment, the $\mathrm{Hg}$ (in the form of cinnabar) will be stable and unavailable for further uptake and leaching into the groundwater.

\section{Acknowledgements}

This study was supported and financed in part by the Department of Science \& Technology - Philippine Council for Advance Science \& Technology Research \& Development (DOST-PCASTRD), the Office of the Vice-Chancellor for Research \& Development (OVCRD), UP Diliman, and the Cordillera Studies Center. 
Bizily S., Rugh C., Summers A. O., and Meagher R. B. (1997), Phytoremediation of methyl mercury pollution: mer B expression in Arabidopsis thaliana confers resistance to organomercurials. Proc. Natl. Acad. Sci. USA 96, 6808-6813.

Briat J. F. and Lebrun M. (1999), Plant Responses to Metal Toxicity. Academie des Sciences-Elsevier, Paris, pp. 43-54.

Bruns I., Friese K., Markert B., and Krauss J. (1999), Heavy metal inducible compounds from Fontinalis antipyretica reacting with Ellman's reagent are not phytochelatins. Sci. Total Environ. 241, 215-216.

Grill E., Winnacker E., and Zenk M. H. (1986), Phytochelatins: Principal heavy metal complexing peptides of higher plants. Science 230, 674-676.

Grill E., Winnacker E. L., and Zenk M. H. (1987), Phytochelatins, a class of heavy metal binding peptides from plants are functionally analogous to metallothioneins. Proc. Natl. Acad. Sci. USA 84, 439-443.

Hayashi Y. and Mutoh N. (1994), Cadystin (phytochelatin) in fungi. In: Metal Ions in Fungi (Winklemann G., and Winge D. R., eds.). Marcel Dekker, Inc., New York, pp. 311-321.

Henry J. R. (2000), Phytoremediation of mercury. In: An Overview of the Phytoremediation of Lead and Mercury: A Report for the U.S. Environmental Protection Agency. Washington, D.C., USA, pp. 44-46.

Keltjens W. G. and van Beusichem M. L. (1998), Phytochelatins as biomarkers for heavy metal toxicity in maize: single metal effects of Co and Cd. J. Plant Nutr. 21, 635-648.

Klaphek S., Fliegner W., and Zimmer I. (1994), Hydroxymethyl-phytochelatins are metal-induced peptides of Poaceae. Plant Physiol. 104, 1325-1332.

Kloke A. (1981), Schwermetalle in Boden und Pflanzen ländlicher und stadtnaher Gebiete. Der Stickstoff 13, 53-61.

Kubota H., Satoh K., Yamada T., and Maitani T. (1995), Phytochelatins (class III metallothioneins) and their desglycyl peptides induced by $\mathrm{Cd}$ in normal roots of Rubia tinctorum L. Plant Sci. 106, 157-166.
Kubota H., Satoh K., Yamada T., and Maitani T. (2000), Phytochelatin homologues induced in hairy roots of horseradish. Phytochemistry 53, 239-245.

Mehra R. K. (1998), Biosynthesis and metal binding characteristics of phytochelatins. In: Pollution Stress, Indication, Mitigation and Conservation. Kluwer Academic, Dordrecht, the Netherlands, pp.360376.

Meuwly P., Thibault P., Schwan A. L., and Rauser W. R. (1995), Three families of thiol peptides are induced by Cd in maize. Plant J. 7, 391-400.

Ohtake Y., Satoce A., and Yabucchi S. (1990), Isolation and characterization of glutathione biosynthesis deficient mutant of Saccharomyces cerevisiae. Agric. Biol. Chem. 54, 3145-3150.

Raskin I. and Ensley B. D. (2000), Phytoremediation of Toxic Metals Using Plants to Clean up the Environment. John Wiley \& Sons, Inc., New York.

Rugh C. L., Wilde H. D., Stack N. M., Marin-Thompson D., Summers A. O., and Meagher R. B. (1996), Mercuric ion reductase abd resistance in transgenic Arabidopsis thaliana plants expressing a modified bacterial merA gene. Proc. Natl. Acad. Sci. USA 93, $3182-$ 3187.

Rugh C. L., Senecoff J. F., Meagher R. B., and Merkle S. A. (1998), Development of transgenic yellow poplar for $\mathrm{Hg}$ phytoremediation. Nature Biotechnol. 16, 925-928.

Satoh M., Karaki E., Kakehashi M., Okazaki E., Gotoh T., and Oyama Y. (1999), Heavy-metal induced changes in nonproteinaceous thiol levels and heavy metal binding peptide in Tetraselmis tetrathele (Prasinophyceae). J. Phycol. 35, 989-994.

Vogeli-Lange R. and Wagner G. (1990), Subcellular localization of $\mathrm{Cd}$ and Cd-binding peptides in tobacco leaves. Plant Physiol. 92, 1086-1093.

Zenk M. (1996), Heavy metal detoxification in higher plants - a review. Gene 179, 21-30. 